\title{
Theory of Constraints in the Service Sector: Characterization for Banking and Analysis of the Factors Involved in Its Adoption
}

\author{
Julian D.M. Castaño ${ }^{1}$, Maria R.A. Moreira ${ }^{1}$, Paulo S.A. Sousa ${ }^{1,2}$, \\ and Raquel F.Ch. Meneses ${ }^{1}$ \\ ${ }^{1}$ Faculty of Economics, Universidade do Porto, Portugal \\ R.Dr. Roberto Frias, s/n, 4200-464 Porto, Portugal \\ julidamo@hotmail.com, \{mrosario, paulus, raquelm\}@fep.up.pt \\ ${ }^{2}$ LIAAD-INESC Porto LA, Portugal
}

\begin{abstract}
In this research we represent the major elements of the Theory of Constraints (TOC) in a services environment, specifically for the banking sector, and we analyze the factors involved in the decision to adopt the TOC by companies in this sector.

It was identified that the four elements of the TOC theory, throughput, inventory, operating expenses and constraints, correspond to, respectively, the money coming from financial services rendered, the money required to generate this profit, the money to fund the expenses, and the limitations to the normal activity. Regarding the constraints, the most common are mainly administrative (regulations and policies) and the lack of technological resources associated to the scarcity of capital flow and the environment imposed by the state of the economy at a specific time.

The main factors that influence the decision to adopt the TOC by the banking sector reside, first, in the tool's current level of development; second, in the nature and the characteristics of the banking service that are very far from the original industrial reality and, finally, in organizational factors such as the attitude towards change, the leadership of the administration and the commitment of the entire institution.
\end{abstract}

Keywords: Services, Banking sector, Theory of Constraints.

\section{Introduction}

The services sector accounts for $67.01 \%$ of the gross domestic product (GDP) of the total world economy and 55\% in the more developed economies [1]. In the case of the countries belonging to the OECD, the services sector has become a driving force in the growth of employment, accounting for over $70 \%$ of the current total. However, in most of these countries, productivity growth in services continues to be slow, which is why the OECD has drawn attention to the importance of adopting new policies, the use of information technologies, and innovation in products and processes, to match the countries that went through this process successfully, such as Australia and the United States [2]. 
For its part, the Theory of Constraints (TOC) is one of the most widely recognized methods of optimization and continuous improvement by the industry in recent years. Initially developed by Dr. Eliyahu M. Goldratt, in the 1980s, TOC is often used by various industrial companies worldwide, intent on the continuous improvement of their processes and increasing efficiency [3-4]. Examples include Ford Motor Company, General Motors, Motorola, Pharmacia or Unilever, which have obtained positive results related to significant increases in production flow (throughput) and significant reduction in inventory, defects associated with quality, cycle time and lead time [4-5].

The historical success of TOC and the tertiary sector's need to increase its productivity serves to highlight the importance of further investigations that combine these two areas. Although there is a stark shortage of TOC developments specifically for the sector, compared to the vast number of existing studies in industry [6-14], some studies related to the area have shown the relevance of and current interest in the matter, which deserves to be more fully explored from new and different perspectives, the main aim of this study. Actually, the TOC is providing a process of centering the attention on the critical areas' improvement [7], and thus has the potential for much faster improvement. Another contribution for services of TOC method is that it provides techniques of dealing with change [10].

This paper begins with a brief review of the relevant literature on the areas involved in the research (services, banking, TOC and TOC in services). Subsequently, the methodology used is described, followed by the results of a multi-case study (aim 1) and the statistical analysis (aim 2). The paper ends with the conclusion, describing limitations and future topics of study.

\section{$2 \quad$ Literature Review}

\subsection{Services}

A generic, basic and simple definition of the term was proposed by Zeithaml and Bitner [15], which defines services as events, processes and performances. Grönroos [16] defines them as activities that are characterized by their intangible properties, and classifies their production based on the interaction, or not, of consumers, service providers, physical resources or systems.

In addition to the intangible properties, Parasuraman et al. [17] highlight heterogeneity as a property of services, related to the instability of the results in the production of services, which depend on a number of variables, such as service providers, the method used, and the same consumer, among others. The same authors explain the characteristic of inseparability in relation to the inability to break down the different elements that make up a service, as is possible in the case of goods. Meanwhile, Fitzsimons and Fitzsimons [18] state that experiences are perishable, intangible and produced by the same consumer, who necessarily becomes a coproducer. Later, Rubalcaba [19] explains that, in addition, services are a whole dimension of activities and not just one sector, noting, first, that the end result is achieved as a joint achievement between the parties involved and, second, the same properties were described by the authors mentioned above. 
Regarding the classification of services within the existing set of proposals on the subject, this study used the classification of Schmenner [20], as used by Siha [10] in her study, which is considered the forerunner to the present research. The matrix classification of service processes, originally developed by Schmenner [20], proposes four categories based on the variables of work intensity and the degree of interaction and customization: Service factory (low labor intensity and low degree of customer interaction and customization), Mass Service (high labor intensity and low degree of customer interaction and customization), Service shop (low labor intensity and high degree of customer interaction and customization), and Professional service (high labor intensity and high degree of customer interaction and customization).

\subsection{Banking Sector}

Within the universe of existing service organizations, the banking sector was chosen as the focus for this study, since it is extremely regulated, with little variability in processes and highly concentrated (in the European case). A specified unit of analysis (Portuguese banks) would serve as the basis for analysis, as well as allow us to extrapolate the findings. The factors that Santillan-Salgado [21] considered as explanatory of this growth in concentration in the European banking industry are: first, the inclusion of high technology developments in banking activities and the rapid increase of competition linked to the deregulation of the sector and state intervention in times of crisis; second, the process of restructuring the EU region to achieve the creation of a single financial market in 1993; and third, the introduction of the euro from 1999, as the official currency of the majority of the EU countries.

In the Portuguese case specifically, the banking sector has been characterized by strong changes in both its structure and its system, resulting from a process of profound transformations over the last few decades: nationalization of banks in 1974, financial market liberalization in 1984, and recharged growth of competition in the sector [22]. This environment, resulting from the re-privatization of the sector, required a modernization of the traditional banking institutions so that they could remain profitable and competitive in the market. Thus, the Portuguese banking sector adopted the Universal Banking model, which is characteristic of those financial institutions that are able to offer, compared to the traditional bank, a more innovative range of financial services directly or indirectly related to its core business [23-25].

Honoban [26] explains how this process in Portugal, with the adoption of the universal banking model, the re-privatization of banks and the removal of limits on growth for loans [22], has endowed the Portuguese banking system with high levels of liberalism [27], being in fact one of the most drastic regulatory liberalizations in Europe [28].

\subsection{The Theory of Constraints}

At the end of the 1970s, Eliyahu Moshe Goldratt developed a scheduling algorithm for industrial production known as Optimized Production Schedule [29]. It was characterized by fixed rules and parameters designed for use in a computer program. Years later, it was named the Optimized Production Technology (OPT) [4]. 
In 1984, Goldratt published the book The Goal [30], which explains the concepts of OPT but does not delve into the details of its implementation. This information would be the central theme of his sub sequent The Race [31], in which he developed a new system to manage the flow of material called Drum-Buffer-Rope (DRB). But it was only in 1988 that the term "Theory of Constraints" was referred to explicitly, while Goldratt listed the results of all his previous work: "(...) The second, and probably the most important result was the formulation of what I consider an overall theory running an organization. I call it Theory of Constraints and I regard everything I've done before as just a mere derivative of this theory (...)" [32]. At the end of the 1980s, this theory became a tool for continuous improvement focused on processes, which, in the 1990s, would be complemented by the use of logic and Thinking Processes (TPs) as the bases for the resolution of the scenarios on which it is focused. No existing systems can have unlimited resources, because if they did, companies could increase profits without limit [4], [9] and [33-34]. These authors also frame a TOC in the area of continuous improvement and define its goal as the scope of improved organizational performance.

Among the variety of concepts involved in this theory and the extension of the philosophy on which it is based, the term 'restriction' is established as the starting point for all TOC philosophy. In the same publication that first referenced TOC, Goldratt (1988, P.453) defines the constraint as "anything that limits a system from achieving higher performance versus its goal". Regarding performance measurement systems, and based on the assumption that the goal of any business is to generate money, he defines three TOC indicators [3]: throughput (T) is the rate at which the system generates money associated with sales; inventory (I) is the money invested in the system to generate the Throughput; and Operating Expenses (OE) is the money the system spends in turning inventory into throughput [4], [6] and [9].

\subsection{The Theory of Constraints in Services}

TOC is a theory created mainly for industrial process optimization [4], [6-7], [9-10], [12-13] and [35-37]. The terminology used, its indicators, the tools for managing problems, the kind of thinking, their premises and, in general, all the elements involved, were developed according to the specific characteristics of the processes to transform raw material into tangible products [9-10] and [14].

Subsequent to the success of this methodology in the secondary sector and the increasing prominence of the service sector in the world economy, the idea arose of extending the application of TOC beyond traditional borders for which it had been designed [6-7]. Table 1 systematizes the TOC literature with relevance to services.

With respect to the relevant literature, as seen in Table 1, the first countries to publish studies on the application of TOC in various areas within the services sector were the United States, England, Australia and Israel, demonstrating the effectiveness of this philosophy in other areas besides the industrial. Although in recent years the literature related to the topic has significantly increased, the approaches are still too incipient to match the large number of studies on TOC developed for industry [6-7] and [13-14]. 
Table 1. Theory of constraints in services: literature review

\begin{tabular}{|c|c|c|c|c|}
\hline \multicolumn{5}{|c|}{ Theory of Constraints in Services } \\
\hline Authors & Country & Type & Sector & Objetives \\
\hline [46] & Israel & \multirow{11}{*}{ 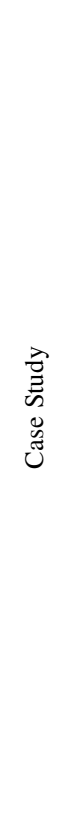 } & Education & $\begin{array}{l}\text { To applying TOC to improve the quality of school education and } \\
\text { productivity. }\end{array}$ \\
\hline [47] & UK & & Health - Consulting & $\begin{array}{l}\text { To modernize mental health services of the UK population } \\
\text { through the merger of the only two service providers. }\end{array}$ \\
\hline [35] & \multirow{10}{*}{ USA } & & Unspecified & $\begin{array}{l}\text { Study the impact of TOC concepts in administrative functions, } \\
\text { applying performance indicators. }\end{array}$ \\
\hline [42] & & & \multirow[b]{2}{*}{ Health } & Improving performance indicators identified in the system TOC. \\
\hline$[6],[7]$ & & & & $\begin{array}{l}\text { Application of TOC for optimization and increased productivity } \\
\text { of nonprofit organizations. }\end{array}$ \\
\hline [43] & & & Construction & $\begin{array}{l}\text { Support improved performance and productivity of the delivery } \\
\text { of the service provided by the company. }\end{array}$ \\
\hline [13] & & & Banking & $\begin{array}{l}\text { To improve credit approval processes and overcome the } \\
\text { constraints of the system. }\end{array}$ \\
\hline [44] & & & Restaurants & $\begin{array}{l}\text { To evaluate the possibility of the successful use of TOC TP } \\
\text { tools to improve the performance of a small business. }\end{array}$ \\
\hline [11] & & & Public Services & $\begin{array}{l}\text { To consider using TOC TP in a public service organization for } \\
\text { service and optimization of the processes. }\end{array}$ \\
\hline [37] & & & Food & $\begin{array}{l}\text { To evaluate the implementation, benefits and feasibility of TOC } \\
\text { as a tool for planning and control of production in the service. }\end{array}$ \\
\hline [45] & & & Consultancy & $\begin{array}{l}\text { Improving the performance of billing system for increased } \\
\text { business productivity. }\end{array}$ \\
\hline [10] & & 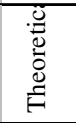 & Service Sector & $\begin{array}{l}\text { To create a classification model for implementing TOC in } \\
\text { different service organizations. Adequacy of vocabulary TOC to } \\
\text { services and developing solutions to potential problems TOC. }\end{array}$ \\
\hline [8] & Australia & 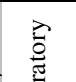 & Banking & $\begin{array}{l}\text { A classified model for Applying the Theory of Constraints to } \\
\text { Service organizations }\end{array}$ \\
\hline [36] & $\begin{array}{l}\text { Australia } \\
\text { / New } \\
\text { Zelanda }\end{array}$ & $\begin{array}{l}\frac{0}{0} \\
\frac{2}{x} \\
\text { 至 }\end{array}$ & $\begin{array}{c}\text { Operational } \\
\text { Research OR/MS }\end{array}$ & $\begin{array}{l}\text { To study TOC TP tools in relation to traditional methodologies } \\
\text { OR / MS for building multi methodological tools. }\end{array}$ \\
\hline
\end{tabular}

Based on the three elements (services sector, banking sector and TOC) and as a result of the analysis of the information extracted from the literature analyzed, this paper aims to, firstly, examine the implementation of the Theory of Constraints in the banking sector, and more specifically, the main TOC concepts (inventory, throughput, operating expenses and restrictions), based on the model to implement TOC for service organizations [9] and the study of the application of TOC in banks [8]. The research of Bramorski et al. [8] was the first one to show how banks can apply the principles of constraint management to improve their processes to obtain competitive advantage. However, it was made using a single bank example and not testing the importance of the several factors. Later on, Reid [13] proposed a five-step sequential process for implementing the TOC concepts. The approach is mainly descriptive and only an example is used to illustrate the framework. Therefore, further studies on the main performance indicators for specific services would be relevant, as they would facilitate the search for more effective solutions to typical problems of these services. 
Next, an analysis is conducted of the factors involved in the decision to adopt TOC by companies in the banking sector, as supported in the literature review.

\section{$3 \quad$ Methodology}

This research can be considered a mixed study inspired by the different approaches and methodologies that were identified during the literature review on TOC in services. In Table 1 we can see the methodology used in several studies.

Initially, the study uses a qualitative methodology with a strong theoretical component and puts forward a proposal for future quantitative validation.

Given the lack of specific literature on the subject, this first theoretical approach is supported by the information extracted from reality through different instruments and it is framed in a multi-case study model. This approach provided the opportunity to include triangulation as a method aimed at achieving accuracy, precision and objectivity in answering the research question: How could TOC elements be characterized in banking?

Subsequently, as part of a quantitative approach to the second aim of the study, Table 2 presents the research hypotheses raised from the review of existing studies in the area.The total number of hypotheses are grouped into three categories according to the affinity of the issues that each addresses and involve some degree of influence on the decision to adopt TOC by banks, based on the level of current development of TOC for application in the banking sector (H1), the nature and characteristics of banking services $(\mathrm{H} 2)$, and the internal management of sector institutions $(\mathrm{H} 3)$.

Given the urgent need to increase productivity and optimize their processes to meet the many challenges that the global economy imposes, the banking sector was selected as the focus for this research. In addition, this sector remains highly regulated, and its operations and services have less variability among the institutions that compose it. Within this universe, Portuguese banks were chosen as the unit of analysis. With regard to the complete sample, the Bank of Portugal (BP) has records of 36 legally constituted and recognized banks, of which 24 are members of the Portuguese Association of Banks (APB), representing 94\% of the banking system's total assets [38-39]. Given the default profile for the study, banks that are highly specialized business units of other banks, without participation in the commercial banking market or institutions without a minimum component of the universal banking concept, were excluded from the study. 24 banks were contacted via direct mail, e-mail and telephone in order to request their participation in the study. Following these contacts, four banks agreed to participate in the multi-case study. A fifth bank was included in the quantitative study, when it decided to participate only in this section of the research process due to time restrictions and internal priorities.

For the study of this sample, and according to the methodologies referred to when defining its two aims, three tools were used for data collection. To develop the multicase study model, semi-structured personal interviews with predefined questions and issues were used. The interview script is divided into six sections (characterization of the interviewee, the bank, inventory, throughput, operating expenses and constraints), grouping 30 questions designed from the findings of the studies by Bramorski et al. [8] and Siha [10]. Also within the qualitative component, a tool was constructed in a matrix format, confronting the bank list for the Universal Banking model [18] with 
the four categories of services proposed by Schmenner [20], which reinforced the information obtained in the interviews, literature and details of the TOC elements within the model Schmenner. Four interviews were conducted in total (two in Lisbon and two in Porto) to high hierarchical level staff, corresponding to the commercial administration, management control and process improvement supervision.

Table 2. Research hypotheses

\begin{tabular}{|c|c|c|}
\hline \multicolumn{2}{|r|}{ Research Hypothesis } & Author \\
\hline \multirow{4}{*}{$\begin{array}{l}\text { H1: The level of } \\
\text { development of TOC } \\
\text { for application in the } \\
\text { banking sector } \\
\text { negatively influences } \\
\text { their adoption by the } \\
\text { banking sector. }\end{array}$} & $\begin{array}{l}\text { H1.1: The existence of TOC indicators for services influences the application of this } \\
\text { theory in the banking sector. }\end{array}$ & [7-8] \\
\hline & $\begin{array}{l}\text { H1.2: The existence of TOC vocabulary for services influences the decision to adopt this } \\
\text { theory in the banking sector. }\end{array}$ & [8], [37] \\
\hline & $\begin{array}{l}\text { H1.3: The existence of a formal method for implementing TOC in services influences their } \\
\text { application in the banking sector. }\end{array}$ & [7], [13-14] \\
\hline & H1.4: TOC is not a recognized tool in the banking sector. $\left({ }^{*}\right)$ & Exploratory \\
\hline \multirow{4}{*}{$\begin{array}{l}\text { H2: The nature and } \\
\text { characteristics of } \\
\text { banking services hinder } \\
\text { the adoption of TOC by } \\
\text { the banking sector. }\end{array}$} & $\begin{array}{l}\text { H2.1: The difficulty in determining the restrictions on banking processes, negatively } \\
\text { influences the adoption of TOC in the banking sector. }\end{array}$ & {$[7-8],[44]$} \\
\hline & $\begin{array}{l}\mathrm{H} 2.2 \text { : Creating TOC as a unique tool for the industrial sector, negatively influences their } \\
\text { adoption by the industry. }\end{array}$ & [13], [37] \\
\hline & $\begin{array}{l}\text { H2.3: The particular characteristics of the services are crucial to the decision to apply } \\
\text { TOC in the banking sector. }\left(^{*}\right)\end{array}$ & $\begin{array}{l}{[6-8],[10],} \\
{[13-14],[37]}\end{array}$ \\
\hline & $\begin{array}{l}\text { H2.4: The nature of restrictions on services difficult to detect and thus, negatively } \\
\text { influences the decision to apply TOC in the banking sector. }(*)\end{array}$ & $\begin{array}{c}{[6-8],[13]} \\
{[44]}\end{array}$ \\
\hline \multirow{9}{*}{$\begin{array}{l}\text { H3: The adoption of } \\
\text { TOC in the banking } \\
\text { sector depends on the } \\
\text { internal management of } \\
\text { sector institutions. }\end{array}$} & $\begin{array}{l}\text { H3.1: The organizational commitment of banking institutions determines the success of } \\
\text { the application of TOC in the sector. }\end{array}$ & [40], [42] \\
\hline & $\begin{array}{l}\text { H3.2: Resistance to change in the organization, hinders the implementation of TOC in } \\
\text { banking sector companies. }\end{array}$ & [45], [47] \\
\hline & $\begin{array}{l}\text { H3.3: The adoption of TOC in banks depends on motivation and leadership generated } \\
\text { by management. }\end{array}$ & [40], [47] \\
\hline & $\begin{array}{l}\text { H3.4: The innovative culture of the bank determines the adoption of TOC to optimize } \\
\text { their processes. }\end{array}$ & $\begin{array}{l}{[37],[42],} \\
\quad[44]\end{array}$ \\
\hline & $\begin{array}{l}\text { H3.5: The absence of systematic, disciplined and with attention to detail processes in the } \\
\text { banking companies, hinders the application of TOC in improving their processes. }\end{array}$ & [44], [45] \\
\hline & H3.6: Banks do not have a formal policy of continuous improvement. & Exploratory \\
\hline & $\begin{array}{l}\text { H3.7: Banks do not consider that their systems are limited and, therefore, they do not } \\
\text { consider the need for the use of tools such as TOC }\end{array}$ & [33] \\
\hline & H3.8: Professional skills of banking employees determines adoption of TOC. $(*)$ & Exploratory \\
\hline & $\begin{array}{l}\text { H3.9: The bank management provides the resources needed to drive continuous } \\
\text { improvement programs. }(*)\end{array}$ & {$[40]$} \\
\hline
\end{tabular}

(*) These hypotheses will be tested only through the analysis of descriptive statistics. The results obtained on these hypotheses, did not allow an analysis of inferential statistics.

Regarding the analysis of the determinants of adopting TOC by banks, which corresponds to the quantitative component of the study, we used an online survey format with 26 questions directly related to the research hypotheses presented in Table 3 . This questionnaire was subject to a pre-test with two professionals in the area of continuous process improvement and the services sector, a statistician and a director of continuous improvement in a bank. 41 responses were obtained from banking employees from the five banks involved in the study, which are directly related to these institutions' area of continuous improvement and process optimization (51.3\% response rate). 


\section{$4 \quad$ Multi-case Study}

The multi-case study clearly showed that there are four main factors present in the dynamics of the current banking sector, also highlighted in the responses of the banks participating in the characterization of the TOC for the services sector. These are: the importance of technology resources and information systems, the need to increase the quality of their services, the use of human resources, and the current economic situation.

Based on these determinants, and in the case of the banks involved, the results obtained (see Table 3) served to relate the money needed to generate their profit (Inventory) with the use of economies of scale, the proper use of human resources, and capacity and efficiency in the production of services, because as one interviewee said, "the goal is to industrialize the banking business".

Table 3. TOC characterization by type of service in the banking sector

\begin{tabular}{|c|c|c|c|c|}
\hline $\begin{array}{l}\text { Type of } \\
\text { Service }\end{array}$ & Inventory & Throughput & Operating Expenses & Constraints \\
\hline 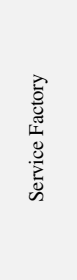 & $\begin{array}{l}\text { Financial resources required } \\
\text { for the production of a } \\
\text { service, whose minimum } \\
\text { investment is maintained, } \\
\text { although these are not sold in } \\
\text { the expected amount. } \\
\text { Example: outsourcing } \\
\text { contracts, agency } \\
\text { representation, technology } \\
\text { applications. }\end{array}$ & $\begin{array}{l}\text { The profit generated from the sale of } \\
\text { banking services, mainly, the interests } \\
\text { associated with home loans, deposits and } \\
\text { trading fees. Gains from the sale of this } \\
\text { service are related to the efficient } \\
\text { management of customer relationships, } \\
\text { management of prices, the bank's image, } \\
\text { the efficiency of its business processes, } \\
\text { streamlining expenses and any situation } \\
\text { maximize the gain from the sale. }\end{array}$ & $\begin{array}{l}\text { Capital invested in the } \\
\text { creation and maintenance } \\
\text { of the distribution } \\
\text { network and the physical } \\
\text { presence of the bank } \\
\text { (agencies, branches, } \\
\text { operations centers, etc.). }\end{array}$ & $\begin{array}{l}\text { - Rigorous policies and excessive } \\
\text { monitoring and control measures of } \\
\text { the government audit institutions. } \\
\text { - Hierarchical structure with } \\
\text { insufficient control in the allocation, } \\
\text { delimitation and compliance functions } \\
\text { of each coworker. }\end{array}$ \\
\hline 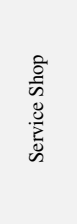 & $\begin{array}{l}\text { Financial resources invested in } \\
\text { production capacity and } \\
\text { delivery of services provided } \\
\text { (distribution network, physical } \\
\text { presence and operations } \\
\text { centers). }\end{array}$ & $\begin{array}{l}\text { The profit generated from the provision of } \\
\text { high quality perceived by the customer and } \\
\text { which compels him to acquire (proximity, } \\
\text { personalization, attention, etc.) }\end{array}$ & $\begin{array}{l}\text { Capital invested in } \\
\text { increasing the efficiency } \\
\text { of processes based on } \\
\text { systematic process } \\
\text { creation and production } \\
\text { of quality services, closer } \\
\text { the ideal established } \\
\text { standard. }\end{array}$ & $\begin{array}{l}\text { - Manual processes without defining } \\
\text { patterns and standards that facilitate } \\
\text { the systematization of operations. } \\
\text { - The variety of services offered and } \\
\text { the complexity of its processes, } \\
\text { problematize the most appropriate } \\
\text { design method of work. }\end{array}$ \\
\hline 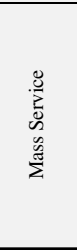 & $\begin{array}{l}\text { Financial resources invested in } \\
\text { the efficiency of service } \\
\text { production areas (backoffice } \\
\text { operations center) and capital } \\
\text { required for its management } \\
\text { (maintenance, updating and } \\
\text { automaización). }\end{array}$ & $\begin{array}{l}\text { The profit generated by the } \\
\text { responsiveness of the sales department } \\
\text { and support areas, when producing a } \\
\text { service requested by the demand. }\end{array}$ & $\begin{array}{l}\text { Capital for the } \\
\text { development of } \\
\text { information technologies } \\
\text { and systems. Automation } \\
\text { of operations. }\end{array}$ & $\begin{array}{l}\text { - Efficiency of the distribution } \\
\text { network and sales force. } \\
\text { - Efficiency of anti-fraud systems } \\
\text { inside and outside the bank (ATM, } \\
\text { credit and debit cards, virtual } \\
\text { transactions, etc) } \\
\text { - Automation of processes related to } \\
\text { the current computing resource } \\
\text { efficiency. }\end{array}$ \\
\hline 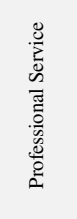 & $\begin{array}{l}\text { Financial resources required } \\
\text { for personnel management in } \\
\text { seeking to achieve the } \\
\text { maximum utilization of human } \\
\text { resources involved in the } \\
\text { commercial and backofficede } \\
\text { support areas (information } \\
\text { systems, operations center). }\end{array}$ & $\begin{array}{l}\text { The profit generated by the proper use of } \\
\text { human resources (commercial department } \\
\text { and support areas) for the provision of } \\
\text { quality of its services. Gains associated } \\
\text { with employees trained and constantly } \\
\text { updated, optimization of existing resources } \\
\text { and increased efficiency. }\end{array}$ & $\begin{array}{l}\text { Capital invested in any } \\
\text { aspect relating to the } \\
\text { management of human } \\
\text { resources in the } \\
\text { production of services. }\end{array}$ & $\begin{array}{l}\text { - Use of human resources and } \\
\text { commercial department backoffice } \\
\text { support. } \\
\text { - Training of the sales force. } \\
\text { - Demand management based on } \\
\text { knowledge of its clients. }\end{array}$ \\
\hline
\end{tabular}

Moreover, it was identified that the money generated by the bank (Throughput) is related to the profit that comes from the provision of these new services, being 
currently responsible for the profits of these institutions, among which the profits generated by trading and commission payment services. It should be noted that this generation of profits continues to liaise with the factors outlined at the beginning of this section and that, depending on the type of service, the weight of its influence varies. In relation to the costs incurred during the process of generating profits (Operating Expenses), the Portuguese banks analyzed continue to refer to the four factors presented at the beginning of the section (technology, human resources, quality, current economy), stating that their main expenses are borne by these situations.

Finally, the concept of constraint for the banks surveyed also corresponds to the claims identified in the literature, which explains that the constraints in services are generally not physical, they are self-imposed through policies and rules [13]. Three of the four banks attach great obstacles to the exercise associated with the existence of a large number of regulations and measures from the national government and the Portuguese central bank. In addition, the banks unanimously regard as restrictions those associated with current methods of work, to craft their processes, customer knowledge and the complexity of the systems. They also highlighted the obstacles imposed by limited technological resources and the influence of the state's economy.

\section{$5 \quad$ Statistical Study}

With regard to the sample, it is observed that most of the banking employees surveyed $(75.6 \%)$ have a bachelor's degree, followed by those with completed secondary education (17.1\%). The remaining percentage is distributed among staff with a master's degree $(4.9 \%)$ and those who have no degree $(2.4 \%)$. Analyzed in more detail, of the group of graduate employees, who represent the majority of the sample, $55 \%$ attended a degree in the area of administration, $33 \%$ in economics, and the remaining $11.1 \%$ are distributed in other areas, such as engineering, computing and marketing. Table 4 shows the results of the tests performed on the hypothesis presented in Table 2.

The statistical analysis shows that, globally, the claims made by the relevant theory are also present in the reality of Portuguese banks. In countries identified as pioneers in the study and application of TOC in services by the literature (USA and UK), the level of development of TOC for this sector is still classified as too young to spread in the same way as it did in the processing industry. Since its inception in 1980, the theory of constraints has evolved with the goal of becoming a highly efficient tool for optimizing the industrial sector; however, the existing theory does not verify the same trend for the tertiary sector. Based on this fact, it was expected that the level of development of TOC for services would influence banking sector companies to adopt this tool and make wide use of it in the financial business. The importance of the specific factors that support this claim (H1.1: Existence of indicators, H1.2: Existence of vocabulary, H1.3: Existence of a specific implementation method) was confirmed in the Portuguese banking reality. The importance of the specific factors that support this claim $(\mathrm{H} 1.1$ : Existence of indicators, H1.2: Existence of vocabulary, H1.3: There is a specific implementation 
method) was confirmed in the Portuguese banking reality. However, it should be noted that, according to the responses from the banking employees surveyed, the majority $(88.9 \%)$ attributed greater influence to the existence of a deployment method [7] and [13-14], while also recognizing the intervention of the other two. Regarding H1.4, it was observed that TOC is one of least well known continuous improvement tools among the banking employees surveyed with $7.3 \%$, being surpassed only by Total Productive Maintenance with $4.9 \%$.

Table 4. Compilation of the results of hypothesis tests

\begin{tabular}{|c|c|c|c|c|c|}
\hline \multicolumn{3}{|c|}{ Hypothesis } & $\begin{array}{c}\text { Statistical } \\
\text { test }\end{array}$ & p-value & Decison \\
\hline \multirow{3}{*}{ H1 } & \multicolumn{2}{|c|}{ H1.1 } & \multirow{3}{*}{ Binomial } & 0.000 & Reject \\
\hline & \multirow{2}{*}{\multicolumn{2}{|c|}{$\begin{array}{l}\text { H1.2 } \\
\text { H1.3 }\end{array}$}} & & 0.000 & Reject \\
\hline & & & & 0.018 & Reject \\
\hline \multirow{3}{*}{$\mathrm{H} 2$} & \multicolumn{2}{|c|}{ H2.1 } & \multirow{3}{*}{ Binomial } & 0.002 & Reject \\
\hline & \multirow{2}{*}{\multicolumn{2}{|c|}{$\mathrm{H} 2.2$}} & & 0.000 & Reject \\
\hline & & & & 0.532 & Retain \\
\hline \multirow{18}{*}{ H3 } & & $\mathrm{H} 3.2$ & \multirow{17}{*}{ McNemar } & 0.007 & Reject \\
\hline & H3.1 & H3.3 & & 1 & Retain \\
\hline & $(*)$ & $\mathrm{H} 3.5$ & & 0.008 & Retain \\
\hline & & H3.8 & & 0.000 & Reject \\
\hline & & H3.1 & & 0.007 & Reject \\
\hline & H3.2 & H3.3 & & 0.001 & Reject \\
\hline & $(*)$ & $\mathrm{H} 3.5$ & & 0.424 & Retain \\
\hline & & H3.8 & & 0.000 & Reject \\
\hline & \multirow{4}{*}{$\begin{array}{c}\mathrm{H} 3.3 \\
(*)\end{array}$} & H3.1 & & 1 & Retain \\
\hline & & H3.2 & & 0.001 & Reject \\
\hline & & H3.5 & & 0.041 & Reject \\
\hline & & H3.8 & & 0.000 & Reject \\
\hline & \multicolumn{2}{|c|}{ H3.4 } & & 0.117 & Retain \\
\hline & \multirow{4}{*}{$\begin{array}{c}\mathrm{H} 3.5 \\
(*)\end{array}$} & H3.1 & & 0.078 & Retain \\
\hline & & $\mathrm{H} 3.2$ & & 0.424 & Retain \\
\hline & & H3.3 & & 0.041 & Reject \\
\hline & & H3.8 & & 0.000 & Reject \\
\hline & \multicolumn{2}{|c|}{ H3.6 } & Binomial & 0.000 & Reject \\
\hline
\end{tabular}

Also related to the design of TOC according to industry, Parasuraman et al. [17] stated that the characteristics of services (intangibility, inseparability, heterogeneity and perish ability) should be carefully studied and taken into account when pursuing research in the area, as they are the conditions that make a significant difference between a service and product. Therefore, the fact that TOC have been designed to interact with characteristics totally contrary to those who own services clearly increases the challenge and, in turn, minimizes the intention of banks to try. Based on the above, it was not surprising to corroborate that the nature and characteristics of services (banking services in this case) are also involved in the decision to implement 
TOC by Portuguese financial institutions (H2). Specifically, it was found that the fact that TOC has been created in the industrial context, also has some degree of influence on whether to adopt $(\mathrm{H} 2.2)$, and that the degree of difficulty to detect restrictions on banking processes has a negative influence on the adoption of TOC (H2.1). The restrictions associated with service delivery systems (regulations, policies, measures, etc.) differ from those of typical industry (physical nature), i.e., being self-imposed and intangible, and they are thus difficult to clearly identify by bank management. With regard to the influence related to the difficulty in detecting the restrictions on services (H2.4), $61 \%$ of the population surveyed recognized that there was a "medium" degree of difficulty in identifying the real factors that limit the bank's processes, $24.4 \%$ consider it as "easy", while 14.6\% reported feeling a "high difficulty". From the above, it should be noted that recognizing the existence of some degree of difficulty in detecting the restrictions by the respondents in this study, could also be a determining factor in the behavior of these banking institutions regarding the use of TOC.

Finally, despite being a statement reiterated by the literature, the responses of the Portuguese banking employees did not allow us to confirm, in general, that bank management is a factor in the adoption of TOC. In fact, $80.6 \%$ of the respondents reported feeling that their bank is committed to the implementation of continuous improvement tools; however, only $2.4 \%$ reported knowledge that TOC had been implemented, a situation that reinforces the independence of these two events (the bank's management and the decision to adopt TOC). However, the results indicate that there are specific factors within management which could become crucial in deciding to implement TOC, such as organizational commitment in implementing continuous improvement programs (H3.1), the attitude towards change (H3.2), motivation and leadership (H3.3), and existence of systematic processes (H3.5).

When relating academic background with knowledge of this instrument $(\mathrm{H} 3.8)$, the results show that the recognition of TOC is concentrated among graduate banking employees $(77.18 \%)$ in areas related mainly to management $(50 \%)$, the remainder being distributed in areas of economics, information technology or marketing. Finally, it was considered important to determine the position of the banks on the availability of resources (not only financial) to drive continuous improvement programs, a crucial factor in the decision to adopt TOC according to Bessant et al. [40]. It is observed that $82.9 \%$ of the respondents recognize the existence of departments dedicated to the implementation of continuous improvement programs to operate processes within the structure of these banks, $36 \%$ of respondents stated that these programs are usually developed by the internal structure of the bank for its own use, $2.8 \%$ state that only existing continuous improvement programs are adopted, and $61 \%$ use both strategies.

\section{Conclusion}

This study proposed a characterization of the main TOC elements (Inventory, Throughput, Operating Expenses and Constraints) according to the different types of services defined by Schemenner [20] and based on studies by Bramorski et al. [8] and Siha [10]. It was found that these TOC elements in banking are closely linked to four 
factors identified in the current global financial sector and in Portuguese banks, which could also influence the results of the multi-case study used in reaching this goal. These are: the importance of technological resources and information systems, the need to increase the quality of their services, the use of human resources, and the current economic situation.

Through the quantitative component of the data analysis performed in this study, we analyzed, for the reality of the Portuguese banking sector, the factors considered by the theory as determinants for organizations to adopt TOC as one of their continuous improvement programs. Based on the responses from the Portuguese banking employees, it was concluded that the current development of TOC for services, and specifically for banking, is still insufficient to enable those companies to include it in their management. It was also possible to infer that the nature and characteristics of services is another factor which greatly limits the adoption of TOC by banks, as their particular properties make their associated restrictions more difficult to identify. Within this aspect, it was also possible to validate that, since TOC emerged within the industrial sector, the Portuguese banking organizations are suspicious of adopting this management tool. Unawareness of the existence of this tool beyond the boundaries of the industry could be one of the biggest obstacles to its spread and development in other fields.

Although the literature noted that the management of these companies is influential on the decision to adopt TOC, the sample did not confirm this assumption. Specifically, some elements in the management of these organizations are crucial in this decision (commitment, attitude towards change, commitment and organizational leadership). However some could not be confirmed (the innovative culture of the company) and others could not be part of the inferential statistical analysis due to the behavior of the responses. The process of this research and the results obtained were somewhat limited, mainly due to the reluctance of most active banks in Portugal to participate in the study. Furthermore, and considering that one of the advantages of conducting personal interviews is the possibility of examining the interviewee responses through additional factors, not only by consciously transmitted information [41], it was possible to detect that some of the banking employees interviewed refrained from responding, with details and faithfully, to questions they considered compromised the bank's privacy.

Also in connection with the information extracted from the Portuguese banking reality, the behavior of the responses was also identified as another limitation to this study. This limitation gives rise to the proposal of a topic for future research, to focus on determining which of these factors are more or less influential on the decision to adopt banking TOC. In this case, the fidelity of the process and results should be safeguarded, with more time for the development of the study, a broader number of participating banks and responses to the questionnaires. With regard to the characterization of the TOC in the sector, having only made a first exploratory approach (corresponding to qualitative multi-case study), the proposal is to compare these results with the reality of the banking sector overall, using the inferential statistical validation techniques similar to those used in the quantitative component of this research. 
Acknowledgement. This work is funded by the ERDF through the Programme COMPETE and by the Portuguese Government through FCT - Foundation for Science and Technology, project PTDC/EGE-GES/099741/2008 and PTDC/EGEGES/117692/2010.

\section{References}

1. UNCTAD: World Investment Report-Transnational Corporations, Agricultural Production and Development. In: United Nations Conference on Trade and Development, New York and Génova (2009)

2. OCDE: Annual Report. The Organisation for Economic Co-operation and Development, Paris (2005)

3. Goldratt, E.M., Cox, J.: The Goal, 2nd edn. North River Press, Croton-on-Hudson (1992)

4. Mabin, V.J., Balderstone, S.J.: The Performance of the Theory of Constraints Methodology: Analysis and Discussion of Successful TOC Applications. Int. J. Oper. Prod. Man. 23(6), 568-595 (2003)

5. AGI: Overview of Results, Goldratt Institute, http://www.goldratt.com/ (accessed on September 26, 2012)

6. Motwani, J., Klein, D., Harowitz, R.: The Theory of Constraints in Services: Part 1 - the Basics. Manag. Serv. Qual. 6(1), 53-56 (1996a)

7. Motwani, J., Klein, D., Harowitz, R.: The Theory of Constraints in Services: Part 2 Examples from Health Care. Manag. Serv. Qual. 6(2), 30-34 (1996b)

8. Bramorski, T., Madan, M., Motwani, J.: Application of the Theory of Constraints in Banks. The Bankers Magazine, 53-59 (1997)

9. Shostack, L.: Breaking Free from Product Marketing. J. Marketing 41(2), 73-80 (1977)

10. Siha, S.: A classified model for applying the theory of constraints to service organizations. Manag. Serv. Qual. 9(4), 255-264 (1999)

11. Shoemaker, T.E., Reid, R.A.: Applying the TOC Thinking Process: A case study in the government sector. Human Systems Manage. 24(1), 21-37 (2005)

12. Ku, E.K.-C.: An Investigation of Theory of Constraints (TOC) and Related Techniques in Health Care Operations. MSc Operations Management, University of Nottingham (2007)

13. Reid, R.A.: Applying the TOC five-step focusing process in the service sector: A banking subsystem. Manag. Serv. Qual. 17(2), 209-234 (2007)

14. Ellis, S.C.: A Theory of Constraints Service Systems Improvement Method: Case of the Airline Turnaround Problem. PhD in Industrial and Systems Engineering, Florida International University (2011)

15. Zeithaml, V., Bitner, M.J.: Service Marketing, 1st edn. McGraw-Hill, New York (1996)

16. Grönroos, C.: Service management and marketing: customer management in service competition. Chichester (2007)

17. Parasuraman, A., Zeithaml, V.A., Berry, L.L.: A Conceptual Model of Service Quality and Its Implications for Future Research. J. Marketing 49(4), 41-50 (1985)

18. Fitzsimons, J.A., Fitzsimons, M.J.: Service Management: Operations, Strategy, and Information Technology. McGraw-Hill, Boston (2011)

19. Rubalcaba, L.: The New Service Economy. Challenges and policy implications for Europe, Cheltenham, UK (2007)

20. Schmenner, R.W.: How can service businesses survive and prosper? Sloan Manage. Rev. 27(3), 21-32 (1986) 
21. Santillán-Salgado, R.J.: Banking Concentration in the European Union during the Last Fifteen Years. Panoeconomicus 2, 245-266 (2011)

22. Canhoto, A.: Portuguese banking: A structural model of competition in the deposits market. R. Financial Econ. 13(s1-2), 41-63 (2004)

23. Bateson, J.E.G.: Do we need service marketing? In: Eiglier, P., et al. (eds.) Marketing Consumer Services: New Insights, Report no. 77-115, pp. 1-30. Marketing Science Institute, Cambridge (1977)

24. Lopes, J.M.G.: Direito Bancário Institucional, Lisboa (2001)

25. Martins, E.F.: Marketing Relacional na Banca. A Fidelização e a Venda Cruzada, Porto (2006)

26. Honoban, P.: Consequences for Greece and Portugal of the opening-up of the European banking market. Development Economics Group, The World Bank (1999)

27. Barth, J.R., Nolle, D.E., Rice, T.N.: Commercial Banking Structure, Regulation and Performance: An International Comparison, US Controller of the Currency. Economics Working Paper 97-6 (1997)

28. Decressin, J., Mauro, P.: The Portuguese banking system: Feeling its pulse on the eve of EMU membership. IMF Country Report 98/127 (1998)

29. Jacobs, F.R.: The OPT Scheduling System: A review of a new production scheduling system. P\&IM J. 24(3), 47-51 (1983)

30. Goldratt, E.M., Cox, J.: The Goal. NorthRiver Press, Croton-on-Hudson (1984)

31. Goldratt, E.M., Fox, R.E.: The Race. NorthRiver Press, New York (1986)

32. Goldratt, E.M.: Computerized shop floor scheduling. Int. J. Prod. Res. 26(3), 443 (1988)

33. Rahman, S.U.: Theory of constraints. A review of the philosophy and its applications. Int. J. Oper. Prod. Man. 18(4), 336-355 (1998)

34. Lubitsh, G., Doyle, C., John, V.: The impact of theory of constraints (TOC) in an NHS trust. J. Manage. Development 24(2), 116-131 (2005)

35. Gillespie, M.W., Patterson, M.C., Bob, H.: TOC Beyond Manufacturing. Industrial Manage. 41(6), 22-25 (1999)

36. Davies, J., Mabin, V.J., Balderstone, S.J.: The theory of constraints: a methodology apart? - a comparison with selected OR/MS methodologies. Omega-Int. J. Manage. S 33(6), 506$524(2005)$

37. Spencer, M.S.: Theory of constraints in a service application: the Swine Graphics case. Int. J. Prod. Res. 38(5), 1101-1108 (2000)

38. BP Instituições Autorizadas: Banco de Portugal, http://www. bportugal .pt/ptPT/Supervisao/Paginas/Instituicoesautorizadas.aspx\#anchor (accessed on September 15, 2012)

39. APB Associados: Associação Portuguesa de Bancos, http: / / www . apb.pt/associados (accessed on March 11, 2012)

40. Bessant, J., Caffyn, S., Gallagher, M.: An evolutionary model of continuous improvement behavior. Technovation 21(2), 67-77 (2001)

41. Saunders, M.N.K., Lewis, P., Thornhill, A.: Research methods for business students, 3rd edn. FT Prentice Hall, Harlow (2003)

42. Gupta, M., Kline, J.: Managing a community mental health agency: A Theory of Constraints based framework. Total Qual. Manage. 19(3), 281-294 (2008)

43. Motwani, J., Vogelsang, K.: The theory of constraints in practice - at Quality Engineering. Manag. Serv. Qual. 6(6), 43-47 (1996)

44. Reid, R.A., Cornier, J.R.: Applying the TOC TP: A case study in the service sector. Manag. Serv. Qual. 13(9), 349-369 (2003) 
45. Taylor III, L.J., Thomas, E.E.: Applying Goldratt's thinking process and the theory of constraints to the invoicing system of an oil and gas engineering consulting firm. Performance Improvement 47(9), 26-34 (2008)

46. Goldratt, R., Weiss, N.: Significant Enhancement of Academic Achievement through Application of the Theory of Constraints (TOC). Human Systems Manage. 24(1), 13-19 (2005)

47. Ritson, N., Waterfield, N.: Managing Change: the Theory of Constraints in the Mental Health Service. Strategic Change 14(8), 449-458 (2005) 